\title{
Not Quite White
}

\section{PAUL OLDHAM}

UNIVERSITY OF SOUTH AUSTRALIA

\section{Jon Stratton}

Jews, Race And Popular Music

Ashgate Publishing Limited, Surrey, England, 2010

ISBN 9780754668046

RRP $€ 55$ (hb)

It is no secret that the architects of the pop song as we know it were the influential Jewish composers Irving Berlin and George Gershwin. Both came from Jewish refugee parents fleeing from Russia to America in the 1890s as a result of the vicious, anti-Semitic Czarist pogroms. The prolific Berlin in particular is considered the father of American song, yet, on his arrival in New York, was unable to speak a word of English and received no formal training. He shot to prominence not with music derived from traditional Synagogue styles or classical music but with his whitened-up adaptation of ragtime, an exciting African-American styled music developed by Scott Joplin and derived from minstrelsy, vaudeville and, of all things, march band music. Berlin's song Alexander's Ragtime Band (1911) kick-started his career and became a worldwide hit which successfully mediated black music to white audiences on a previously unprecedented level. It is a superb seminal example of the great skill which Jewish songwriters and performers have displayed 
throughout the history of popular music to bridge the gap between the music of African-American performers and the tastes of the hegemonic white American culture.

The Jewish experience in Western society is an undeniably odd case of acceptance and prejudice. Even a cursory look over popular culture, especially America popular culture, reveals industries inextricably linked to (and sometimes defined by) Jewish innovators. From Hollywood to the popular music industry, the talents of creative Jews have played an integral part in shaping Western arts since the very beginning-and yet the Jewish people have had to constantly fight for acceptance in the worlds they've helped dream up. It's an odd dilemma to be sure and one which Australian sociologist Jon Stratton tackles with signature passion and deft understanding. Stratton has built a formidable back catalogue of work over the last twenty-five years, taking on many topics including popular music, subculture and Jewishness. In Jews, Race And Popular Music, Stratton expands on his published academic journal articles on Jews and popular culture (three of which are reprinted in an altered form here) to provide a series of case studies that plot a course to uncover the continuing struggles of Jewish performers in Anglophone society to gain acceptance and recognition. Stratton is both Jewish and a British ex-pat, which understandably lends his material an extra layer of credibility.

As the title insinuates, issues of race beat at the heart of Jews, Race And Popular Music. Stratton wastes little time in establishing the complicated interlacing issues of race and popular music. To highlight this, he discusses the wealth of material covering the different positions investigating issues of blackness and popular music that have steadily swollen over recent decades. This literature is crucial to Stratton's story because, as he shows through a fluid, mounting argument, there are many crossovers and parallels between the African-American and Jewish experiences in popular music. Where Stratton's book kicks a major goal is in its widening of the field to offer an international Anglophone perspective with case studies from the United States, Great Britain and Australia. This is worth noting. Time and time again, popular music studies will focus purely on America or, to a lesser degree, Britain. This may have made sense two decades ago but in a world of ever-increasing globalisation this continuing oversight has frustrated the field of popular music studies with glaring omissions stemming from provincial arrogance, 
even ignorance. Stratton maps out the essentially different political contexts and histories of each terrain to illustrate the qualities shared by Jewish performers resisting marginalisation. His book also highlights the specific experiences encountered in each of these countries. The pertinence of this when discussing borderless issues like Jewishness and race should not be lost on any reader.

Stratton delves right back into the deep annals of popular music history to provide solid foundations for his arguments. This approach pays off in dividends because the diverse threads he draws attention to are wound throughout each of his subsequent arguments. He explores the ways in which the dominant American gentile social order of the early twentieth century defined the Jewish people using Orientalised stereotypes, typically involving descriptors such as ugly, untrustworthy, ostentatious, melancholic and exotic. Stratton reveals one root of these prejudicial stereotypes in nineteenth-century scientific racism that not only considered Jews to be black but drew on troublingly eugenicist arguments that proudly promulgated inherent Jewish impurity, hereditary disease and general undesirability. The centrality of these views to American thinking is pointedly underlined by the notable popularity of Madison Grant's inflammatory The Passing of the Great Race (1916), which warned of Jewish genetic inferiority and, in a sideways step, claimed them to be neither black nor white. As the book progresses, Stratton outlines how these very prejudices are heard in implicit resounding echoes even into the twenty-first century. And here lies the heart of his debate. He is able to consistently show how the quality of the performer or songwriter is relegated to a backseat position behind their cultural identity as a Jew instead of as a talent of remark.

The persistence of stereotyping and its effects provides a key theme for Stratton. The strongest example is his examination of the construction of the 'beautiful Jewess' as the exotic, uncivil and Oriental other alongside further issues of blackness and feminism. And, wouldn't you know it, it's the uncivil nature of the 'beautiful Jewess' that aids her in channelling the perceived emotionally expressive African-American vocal style, underlining a key reason she is such a talented mediator of the white and black musical worlds. The Jewess is thus whitened by the process of making African-American music more acceptable to the white audience. Stratton argues that this use of racial stereotypes to marginalise all those 
performers identified as Jews dramatically affects the construction of their identities, choice of material and the ways in which they are received by their audience.

This goes some way to explain the importance of African-American music to the careers of Anglophone-Jewish artists. As Stratton explains:

Sometimes Jews have, consciously or not, utilised African-American culture as a way of gaining whiteness. Sometimes they have used it as a way of expressing their disillusionment with white culture. Always, Jews have channelled aspects of African-American culture into white culture, most importantly in music the emphasis on emotional expression and the practices through which that emotional expression is given form. (198)

Stratton shows that this was a central factor in the ways 1960s counterculture Jewish performers played key roles in electrified blues boom as well as the folk revival of the early-to-mid 1960s. It is also an integral to why the Beastie Boys became the first hip hop group to crossover into the white mainstream in the 1980s. Stratton's argument for the various ways in which African-American music has been whitened throughout the history of popular music is part of what could be considered one of his overarching projects. He also discusses this at some length in his Australian Rock: Essays on Popular Music (2007) where he talks about the music of the Beatles, the Rolling Stones and the Yardbirds and how their appropriation of blues was whitened even further when filtered through popular Australian 1960s bands such as The Aztecs, The Easybeats and The Twilights.

Stratton's eight separate yet cleverly imbricated case studies cover much ground and their interrelations defy easy explanation. For instance, one strain describes the roots of the American-Jewish relation to the torch song and, if you'll pardon my French, 'coon shouting' traditions of the late nineteenth century. As Stratton establishes, torch singing is the style of passionately sung romantic ballad, typically an unrequited love lament. The unfortunately named 'coon shouting', on the other hand, is type of loud and robust singing popularised by predominantly female, untrained vocalists and derived from the blues field hollers of AfricanAmericans workers. More to the point, it was performed by Jewish women (originally in blackface) - such as Fanny Brice and Sophie Tucker-as part of the minstrelsy genre. He then picks up the story forty years later where many of these 
issues are now transposed over the Jewish soul pop Brill Building songwriters of the early 1960s. The sociopolitical climate may have changed considerably but the cases bear much similarity. He then interpolates the issues in an entirely different context during the torch song renaissance of the 1960s and '70s, courtesy of the differing cases of Barbra Streisand and Bette Midler. For each step in his examination, Stratton makes special note of the changes in Jewish visibility and the subtle (and not so subtle) differences in complexity and commonality occurring in the relationships between Jewish and African-American performers or songwriters.

The political and cultural terrain then changes as Stratton investigates the different experience and challenges of British songstress Helen Shapiro. Shapiro became a major star in the early 1960s and even had the Please Please Me-era Beatles as a support act on her 1963 national tour. But Stratton shows that she was subject to many specifically English issues of racialisation. He contends that, once again, the key to Shapiro's success was her exotic status and pronounced ability to whiten African-American music to a level deemed acceptable to her white English audience. Stratton expounds upon this point with his study of the more recent parallel cases of Britain's proudly Jewish Amy Winehouse and Top-40 pop singer Rachel Stevens (ex S Club 7). Here he reveals the troubling prejudicial lens to be alive and well and strong as ever in the politically correct twenty-first century. He not only shows the similarities between Winehouse and Shapiro but also how the stereotyped Jewess image has been consistently used by the media to discuss both Stevens and Winehouse.

A new ring of complexity is added to Stratton's exploration with the inclusion of an Australian cultural tale which again shifts the political terrain to compare the tales of gritty Australian-Jewish blue-eyed soul singer Renée Geyer and then-novelty African-American immigrant Marcia Hines. He describes how Hines managed to gain acceptance through the whitening of her material whereas the more hot-blooded Geyer became whitened by her uncompromising dedication to African-American music. Throughout these successive chapters, Stratton stacks up his evidence to illustrate how reductive constructed concepts have survived, morphed and thus perpetuated throughout the history of popular music and culture. In discussing the plights of Jewish performers in three distinctly different Anglophone environments, Stratton manages the extraordinary task of revealing not 
just the differences but more importantly the similarities of the experiences each Jewish performer lives through.

With Jews, Race And Popular Music, Stratton has done as he did with his previous examinations of Australian rock, subculture and multiculturalism: injected new life, insight and enthusiasm for a seemingly familiar subject to cast it in a fascinating new light. For instance, his chapter on the Brill Building songwriters' production house takes a much discussed area and provides a cultural spin that somehow makes more sense of the integral empathy which existed between the suburban Jewish experience in late 1950s and early 1960s America and the AfricanAmerican performers who drove their songwriting to the top of the charts. This is then infused with pioneering Jewish feminist Betty Friedan's acute understanding of the disenchantment felt by white, bored housewives. Stratton's point is that songwriters such as Carole King and Barry Goffin, Jerry Leiber and Mike Stoller, and Ellie Greenwich were normal Jewish kids. If they struck a nerve with mainstream white American teens, it was because they were unconsciously expressing their utopian Jewish desire for acceptance in America as love songs. In the same way the expressive 'miniature sound stories' of torch songs had spoken of unrequited love, so too these Brill Building songwriters expressed another kind of spurned yearning. (21) Stratton also notes that the discomfort these early 1960s songwriters found in the empty promise of the American dream was famously echoed by Friedan's displeasure at constrictive gender roles. However, Stratton contends that while Freidan asked the question 'is this all?' on behalf of all suburban housewives, 'what Jewish women and their husbands had found out, in addition, was that being whitened did not bring acceptance. As Jews, they remained excluded from the WASP culture of suburbia.' (41)

Once again Stratton writes with a vigorous and vibrant grasp of his subjects. Jews, Race And Popular Music is encyclopaedic and multi-layered in scope and delivers a valuable contribution to popular music studies. 
Paul Oldham is a researcher at the University of South Australia. He has been a practising professional popular music and culture journalist since 1993 and is currently music writer for Sunday Mail (Adelaide). 